\title{
Managers Knowledge and Attitude of Educational Hospitals of Qazvin University of Medical Sciences toward Strategic Planning, 2016
}

\author{
Naser Derakhshani ${ }^{1}$, Saber Azami-Aghdash ${ }^{2}$, Mahdiyeh Heydari ${ }^{1}$, Behzad Eshtiag ${ }^{1}$, \\ Ramin Rezapour ${ }^{1 *}$ \\ ${ }^{1}$ MSc student, Iranian Center of Excellence in Health Management, Department of Health Service Management, \\ School of Health Management and Medical Informatics, Tabriz University of Medical Sciences, Tabriz, Iran \\ ${ }^{2}$ Assistant professor, Tabriz Health Services Management Research Center, Iranian Center of Excellence in \\ Health Management, School of Management and Medical Informatics, Tabriz University of Medical Sciences, \\ Tabriz, Iran
}

*Corresponding Author: Ramin Rezapour, Department of Health Services Management, Iranian Center of Excellence in Health Management, Tabriz University of Medical Sciences, Tabriz, Iran

\begin{abstract}
:
Background: Hospitals, as a complex and changing industry, require comprehensive and strategic planning. The role of managers as the main executors of the strategic planning process is very important in this regard. The purpose of this study is Managers Acknowledge and Attitude of Educational Hospitals of Qazvin University of Medical Sciences Toward Strategic Planning.
\end{abstract}

Materials and Methods: This is a cross-sectional study carried out with 22 senior and middle managers of hospitals affiliated to Qazvin University of Medical Sciences in 2016. To collect data, we used the valid and reliable questionnaire for measuring the level of awareness and attitude towards strategic planning and SPSS:24 software was used to analyze the data.

Results: The mean total awareness and attitude towards strategic planning was calculated as $72.2 \%$ and $89 \%$, respectively. Hospital managers with $84 \%$ awareness had the highest, and hospital presidents with $60 \%$ awareness had the lowest awareness about strategic planning. Regarding the 'attitude', hospital managers with $91.56 \%$ had the highest, and hospital presidents with $83.78 \%$ had the lowest attitude rate.

Conclusion: Given the low level of awareness and attitude of the hospital presidents towards strategic planning in comparison with other senior managers of hospitals, increasing their awareness and improving their attitudes, due to their critical position and authority, is of great importance.

Keywords: Strategic planning, hospital management, awareness, attitude, senior managers

\section{INTRODUCTION}

The health industry has a dynamic and complex environment. The increasing development of private and public hospitals and the improvement in their services and the ever-increasing advances in medical technology have put hospitals in a special competitive environment[1]. In this regard, managers and leaders in hospitals should deal with these changes by being farsighted, anticipating and analyzing environment changes, being flexible in making decisions about environment changes, and formulating the appropriate path to achieve the goals of the organization $[2,3,4,5,6]$.

In order to cover the competitive space and environment changes, health and medical organizations need to pay special attention to management tools, particularly appropriate planning. Planning as part of the management process is essential to the success of the organizations, and this is especially true of health and medical organizations[7]. Today's organizations, especially hospitals, need to have a strategic plan that looks to the future[8,9]. Nowadays, major and rapid changes in hospital environment make the necessity and importance of strategic planning all the more apparent[2,10]. Strategic planning, as an absolutely useful and reliable tool, can be a guide and roadmap to any 
organization, especially health and medical organizations[11]. Strategic planning is a process that is designed and implemented to achieve the organization's goals in competitive, dynamic, and changing environments through the optimal allocation of resources, and in designing a strategic plan based on the current situation envisions the desired future as well[10,11,12,13]. If the managers do not have the appropriate and adequate awareness and attitude in formulating the strategic planning, it may eventually lead to the waste of resources, including time, financial resources, workforce, etc. [14].

In a study by Karimi (1994) in Isfahan, most of the managers studied were relatively aware of planning, and in hospitals where the managers had acceptable planning awareness, bed occupancy rate was high, average inpatient stay was low, and the ratio of bed occupancy day to total bed day was optimal[15]. As for the importance of hospital managers' awareness of strategic plan, in a study conducted in Serbia, the importance of strategic planning, teaching it, and the implementation of strategic management for hospitals in a competitive context was further emphasized[5]. In a study by Abedini et al. titled "Awareness and attitude of the Iranian Medical Science University managers towards development and application of strategic planning" in 2003, the context and environment was not evaluated suitable and ripe for the implementation of the strategic planning in Iran University of Medical Sciences; however, the attitude and awareness of managers in designing and applying the strategic plan was concluded as adequate and acceptable[16].

In order to achieve the long-term goals of hospitals, strategic planning offers a framework for the promotion and improvement of all the activities and programs, management, communication with the external and internal environment of the hospital, and assessment off the current and optimal state of hospitals[17]. In order to foster and promote hospital performance and functioning and achieve success in a changing and evolving world, strategic planning makes its borders flexible and creates an adaptable and suitable organizational culture[18].

In spite of the importance of strategic planning and the importance of time and resources used to develop it, many of the strategies developed in hospitals are not properly implemented due to the absence of proper awareness and attitude on the managers' side[19]. Therefore, the present study aims to determine the level of awareness and attitude of the managers, presidents, matrons, and financial and administrative officials of the educational hospitals of Qazvin University of Medical Sciences based on their demographic characteristics.

\section{Materials And Methods}

This research is a cross-sectional descriptive-analytic study of the presidents, hospital managers and nursing managers (matrons), and financial managers and administrative officials of educational hospitals affiliated to Qazvin University of Medical Sciences in 2016. The statistical population consists of 22 senior managers. Due to the small size of the research population, the sampling process was carried out in the form of a census, and the research sample was adjusted to the population.

To collect data, the questionnaire to measure the awareness and attitude of managers towards the formulation and application of the strategic plans, whose content credentials have been evaluated by the management experts and in evaluating its scientific credentials it is also stated that 100 percent of the questions are understandable to the managers, was used. The reliability of this questionnaire has also been confirmed by Test-retest test, with the correlation coefficient of $92 \%$ and $86 \%$ [16]. The questionnaire consists of three sections: the first part includes the demographic information, the second part the questions related to the degree of managers' awareness of the formulation and application of the strategic plan, and the third part includes questions related to the assessment of the attitude of managers toward the formulation and application of the strategic plan. Questions related to 'awareness' were presented as multiple-choice tests and questions about 'attitude' were produced according to the 5-point Likert scale, which evaluated the attitude from very low to very high. To calculate the awareness level of managers regarding the formulation and application of the strategic plan, for each person, the number of correct answers was divided into the total number of the questions, and the total awareness was calculated from the mean score of all of the participants. In 
calculating the 'attitude', a score of 1 to 5, based on the Likert scale, was specified, score 1 meaning very little or low agreement and score 5 very high agreement, and to compute it, all of the scores for each scale were added together, then divided to the maximum attitude level, for which the number of questions is multiplied by 5 , and in this way the attitude level for each person was calculated; and for calculating the total attitude, the average score of the attitude of all people was estimated. For both awareness and attitude levels, getting a score of higher than $66 \%$ was considered and meant good awareness and positive attitude, a score between 33-66\% meant average and moderate awareness and attitude, and a score lower than $33 \%$ signified poor awareness and negative attitude.

The permit for the research was obtained from Qazvin University of Medical Sciences. Also, in collecting the data, 'informed consent' was obtained from all of the participants.

For data analysis, descriptive statistics (percentage, frequency, mean, etc.) and analytical statistics including Spearman correlation coefficient, Kendall correlation coefficient, and chi-square test were used to examine the relationship between variables and the variable mean difference in different groups. SPSS:24 software was used for the analysis. In this study, the value of P-value less than $0.05 \%$ was considered statistically significant.

\section{RESUltS}

The results showed that out of 22 participants in the study $68 \%$ were male. Subjects were put into four age groups, with the lowest number of participants going to the age group less than 30 years old (4\%) and the highest number of participants to the age group between 40 and 50 years (55\%). Regarding in-service training, $73 \%$ (16 people) had passed in-service management training course and only $18 \%$ (4 persons) had passed in-service strategic planning training (Table 1).

Table1. Academic and demographic characteristics of participants (22 people)

\begin{tabular}{|c|c|c|c|c|c|}
\hline Variable & Variable levels & Number(\%) & Variable & Variable levels & Number(\%) \\
\hline \multirow{5}{*}{$\begin{array}{l}\text { Organizational } \\
\text { position }\end{array}$} & president & $3(13 \%)$ & \multirow{5}{*}{ Field of Study } & Management & $7(32 \%)$ \\
\hline & manager & $5(23 \%)$ & & medical & $4(18 \%)$ \\
\hline & matron & $5(23 \%)$ & & Nursing & $6(27 \%)$ \\
\hline & $\begin{array}{l}\text { Administrative } \\
\text { Officer }\end{array}$ & $5(23 \%)$ & & Accounting & $4(18 \%)$ \\
\hline & $\begin{array}{l}\text { Financial } \\
\text { Management }\end{array}$ & $4(18 \%)$ & & Economy & $1(5 \%)$ \\
\hline \multirow{3}{*}{ life of service } & Under 5 years old & $1(5 \%)$ & \multirow{8}{*}{ education } & \multirow{3}{*}{ Bachelor } & \multirow{3}{*}{$9(41 \%)$} \\
\hline & 10 to 20 years & $11(50 \%)$ & & & \\
\hline & 20 to 30 years & $10(45 \%)$ & & & \\
\hline \multirow{5}{*}{$\begin{array}{l}\text { Work } \\
\text { experience in } \\
\text { management } \\
\text { post }\end{array}$} & $\begin{array}{lll}\text { under } & 10 & \text { years } \\
\text { old } & & \end{array}$ & $8(36 \%)$ & & \multirow{3}{*}{ Masters } & \multirow{3}{*}{$9(41 \%)$} \\
\hline & 10 to 20 years & $13(59 \%)$ & & & \\
\hline & 20 to 30 years & $1(5 \%)$ & & & \\
\hline & 10 to 20 years & $13(59 \%)$ & & \multirow{2}{*}{$\mathrm{PhD}$} & \multirow{2}{*}{$4(18 \%)$} \\
\hline & 20 to 30 years & $1(5 \%)$ & & & \\
\hline
\end{tabular}

The average total awareness of strategic planning for the target society was calculated as $72.2 \%$, where hospital managers had the highest (84\%) and hospital presidents the lowest level of awareness (60\%) about the strategic planning (Table 2).

In attitude survey, the overall mean score of attitude toward strategic planning was estimated at $89 \%$, with the highest attitude score belonging to the managers with $91.56 \%$ and the lowest to the hospital presidents with $83.78 \%$ (Table 3).

From the different groups of senior managers surveyed, hospital managers had the highest level of awareness and attitude toward strategic planning, while hospital presidents, in contrast, had the lowest level of awareness and attitude (Chart 1). 


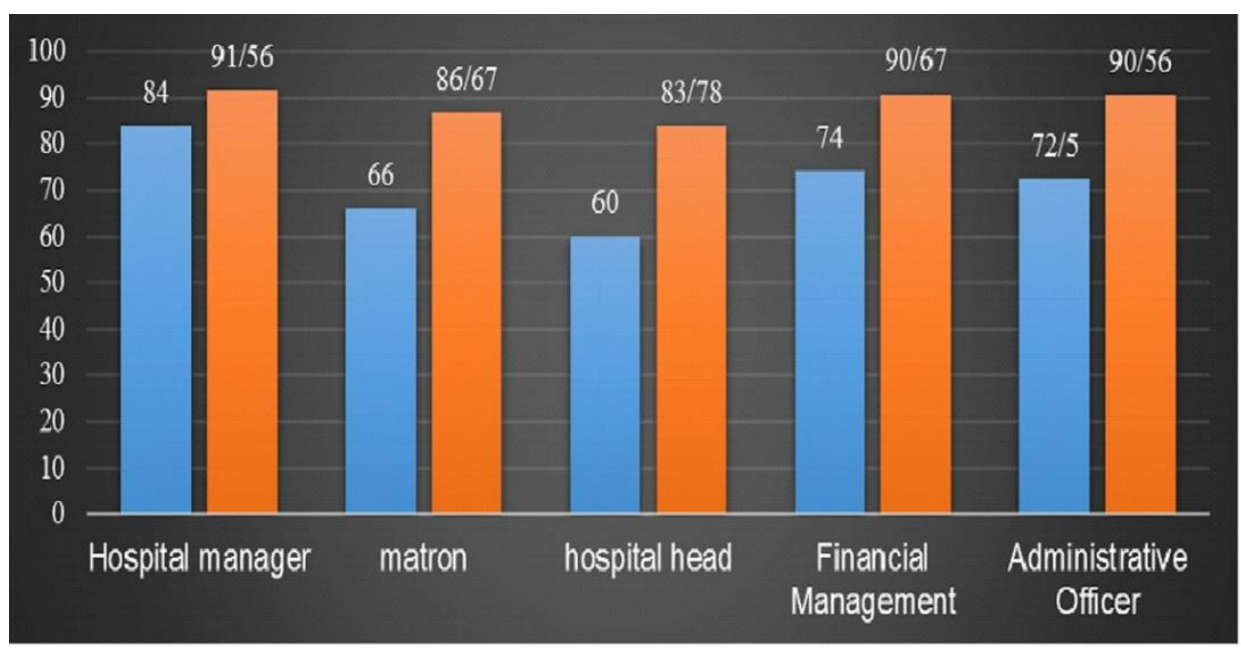

Chart1: Comparison of mean score of Awareness and attitude among different groups of organizational posts

There is a meaningful correlation between awareness and attitude toward strategic planning ( $\mathrm{p}$-value $=0.035$ ), so that increased awareness about the development and application of the strategic plan leads to better and more positive attitude among the participants. The results of statistical tests on the relationship between demographic information and other variables of the study with awareness and attitude are shown in Table 4.

P-value *

Table 2. Awareness of top managers of Qazvin hospitals about strategic planning in 2016

\begin{tabular}{|c|c|}
\hline Awareness Questions & $\begin{array}{l}\text { Number (percent) } \\
\text { the correct answer }\end{array}$ \\
\hline $\begin{array}{l}\text { Which of the following is not correct? } \\
\text { 1. Strategic planning is a reflection of the values of } \\
\text { society. } \\
\text { 2. Strategic planning is focused on the main } \\
\text { question dna the fundamental issues of } \\
\text { organization. } \\
\text { 3. Strategic planning takes place at the executive } \\
\text { level. } \\
\text { 4. Strategic planning has a long-term vision. }\end{array}$ & $13(59 \%)$ \\
\hline $\begin{array}{l}\text { Which of the following is not correct? } \\
\text { 5. Strategic planning is a reflection of the values of } \\
\text { society. } \\
\text { 6. Strategic planning is focused on the main } \\
\text { question dna the fundamental issues of } \\
\text { organization. } \\
\text { 7. Strategic planning takes place at the executive } \\
\text { level. } \\
\text { 8. Strategic planning has a long-term vision. }\end{array}$ & $13(59 \%)$ \\
\hline $\begin{array}{l}\text { Evaluation of internal and external environment of } \\
\text { the organization in the preparation of the strategic } \\
\text { plan are: } \\
\text { 1. A list of Goals } \\
\text { 2. A list of strategies } \\
\text { 3. A list of strategic issues and issues } \\
\text { 4. A list of specific goals (Objectives) }\end{array}$ & $9(41 \%)$ \\
\hline $\begin{array}{l}\text { Which of the following is discussed when we are } \\
\text { doing SWOT analysis? } \\
\text { 1. Strengths and weaknesses, goals and threats } \\
\text { 2. Strengths or weaknesses, opportunities and } \\
\text { timelines } \\
\text { 3. Strengths or weaknesses, goals and timelines }\end{array}$ & $13(59 \%)$ \\
\hline
\end{tabular}




\begin{tabular}{|c|c|}
\hline $\begin{array}{l}\text { 4. Strengths and weaknesses, opportunities and } \\
\text { threats }\end{array}$ & \\
\hline $\begin{array}{l}\text { Which of the following represents the characteristics } \\
\text { of the organization's mission statement? } \\
\text { 1. The mission statement is broadly indicative of a } \\
\text { specific destination. } \\
\text { 2. The mission statement should be continued. } \\
\text { 3. The mission statement must emphasize the unity } \\
\text { and integrity of the organization. } \\
\text { 4. All items }\end{array}$ & $20(91 \%)$ \\
\hline $\begin{array}{l}\text {............ In fact, it represents how will be the } \\
\text { organization in the future? } \\
\text { 1. Mission } \\
\text { 2. vision } \\
\text { 3. values and principles governing the organization } \\
\text { 4. objectives }\end{array}$ & $21(95 \%)$ \\
\hline $\begin{array}{l}\text { Objectives is clear,........., achievable, realistic and } \\
\text { relevant? } \\
\text { 1. measurable } \\
\text { 2. based on mission } \\
\text { 3. maximum } \\
\text { 4. financially }\end{array}$ & $22(100 \%)$ \\
\hline $\begin{array}{l}\text { perspective at the values and views of people and } \\
\text { staff in the delivery of services? } \\
\text { Mission } \\
\text { 1. Vision } \\
\text { 2. Values } \\
\text { 3. Objectives }\end{array}$ & $15(68 \%)$ \\
\hline $\begin{array}{l}\text { Which of the following steps is the last step in } \\
\text { formulating strategic planning? } \\
\begin{array}{lll}\text { 1. Determine the strategy } & \text { 2. Implement the } \\
\text { program } & \text { 3. Assess and modify the plan } & \\
\text { Determine the goals and objectives. } & \end{array}\end{array}$ & $18(82 \%)$ \\
\hline $\begin{array}{l}\text { The concept of strategic planning in hospital is: } \\
\text { 1- Work plan 2. way and method of achieving goals } \\
\text { 3- Activity timetable. } 4 \text {. Hospital policies }\end{array}$ & $10(45 \%)$ \\
\hline $\begin{array}{l}\text { The awareness of the whole society studied } 22 \\
\text { manager (average answer true or false to all } \\
\text { questions) }\end{array}$ & $(72.2 \%)$ \\
\hline
\end{tabular}

Table 3. Attitude of top managers of Qazvin hospitals about strategic planning in 2016

\begin{tabular}{|l|l|l|l|l|l|}
\hline \multicolumn{1}{|c|}{ Attitude questions } & $\begin{array}{l}\text { Very much } \\
\text { People (\%) }\end{array}$ & $\begin{array}{l}\text { High } \\
\text { People (\%) }\end{array}$ & $\begin{array}{l}\text { High } \\
\text { People (\%) }\end{array}$ & $\begin{array}{l}\text { Low } \\
\text { People (\%) }\end{array}$ & $\begin{array}{l}\text { Very } \\
\text { People (\%) }\end{array}$ \\
\hline $\begin{array}{l}\text { 1. How much is it necessary to } \\
\text { formulate strategic planning for a } \\
\text { hospital? }\end{array}$ & $21(95 \%)$ & $1(5 \%)$ & $1(5 \%)$ & - & - \\
\hline $\begin{array}{l}\text { 2. How much do you consider the } \\
\text { involvement of hospital managers } \\
\text { in formulating the strategic plan }\end{array}$ & $17(77.3 \%)$ & $5(22.7 \%)$ & $5(22.7 \%)$ & - & - \\
\hline $\begin{array}{l}\text { 3. How much is it necessary to } \\
\text { evaluate the external and the } \\
\text { internal environment of hospital } \\
\text { to formulate strategic planning? }\end{array}$ & $15(68.1 \%)$ & $5(22.8 \%)$ & $5(22.8 \%)$ & - & - \\
\hline $\begin{array}{l}\text { 4. How much do you think the } \\
\text { implementation of the strategic } \\
\text { plan is effective in solving the } \\
\text { major hospital problems? }\end{array}$ & $7(31.8 \%)$ & $12(54.5 \%)$ & $12(54.5 \%)$ & - & - \\
\hline $\begin{array}{l}\text { 5. How much do you permit the } \\
\text { flexibility in the strategic plan of } \\
\text { the hospital? }\end{array}$ & $6(27.2 \%)$ & $9(40.9 \%)$ & $9(40.9 \%)$ & - & - \\
\hline
\end{tabular}


Managers Knowledge and Attitude of Educational Hospitals of Qazvin University of Medical Sciences toward Strategic Planning, 2016

\begin{tabular}{|l|l|l|l|l|l|}
\hline $\begin{array}{l}\text { 6. How much do you think to } \\
\text { implement the strategic plan to } \\
\text { accelerate the development of the } \\
\text { hospital? }\end{array}$ & $11(50.1 \%)$ & $9(40.9 \%)$ & $9(40.9 \%)$ & - & - \\
\hline $\begin{array}{l}7 . \text { How much do you think the } \\
\text { hospital staff contribution is } \\
\text { necessary in implementing a } \\
\text { strategic plan? }\end{array}$ & $15(68.1 \%)$ & $6(27.2 \%)$ & $6(27.2 \%)$ & - & - \\
\hline $\begin{array}{l}8 . \text { How much do you need to } \\
\text { consult with people outside the } \\
\text { hospital in developing a strategic } \\
\text { plan? }\end{array}$ & $2(9 \%)$ & $10(45.1 \%)$ & $10(45.1 \%)$ & $1(5 \%)$ & - \\
\hline $\begin{array}{l}\text { 9. How much do you implement } \\
\text { the strategic plan to determine the } \\
\text { future orientation and improve the } \\
\text { performance of the hospital? }\end{array}$ & $21(95 \%)$ & $1(5 \%)$ & $1(5 \%)$ & - & - \\
\hline $\begin{array}{l}\text { 10. The attitude of the whole } \\
\text { society studied 22 manager } \\
\text { (average answer for each item) }\end{array}$ & $55 \%$ & $33 \%$ & $33 \%$ & $1 \%$ & - \\
\hline
\end{tabular}

Table4. The results of statistical tests on the relationship between demographic information and other variables of the study with knowledge and attitude

\begin{tabular}{|c|c|c|l|c|}
\hline $\begin{array}{c}\text { In-service } \\
\text { training courses } \\
\text { in strategic } \\
\text { planning }\end{array}$ & $\begin{array}{c}\text { In-service training } \\
\text { courses in } \\
\text { management }\end{array}$ & Field of Study & $\begin{array}{l}\text { Level of } \\
\text { Education }\end{array}$ & $\begin{array}{c}\text { Study variables } \\
\text { Oimension }\end{array}$ \\
\hline$\underline{\mathbf{0 . 0 1 5}}$ & 0.12 & 0.21 & $\underline{\mathbf{0 . 0 0 2}}$ & awareness \\
\hline$\underline{\mathbf{0 . 0 1 3}}$ & 0.32 & $\underline{\mathbf{0 . 0 2 5}}$ & $\underline{\mathbf{0 . 0 0 9}}$ & Attitude \\
\hline
\end{tabular}

\section{DISCUSSION}

The results of the study demonstrated that the average level of awareness of the different groups was at a good level and their attitude was also estimated as positive. In all of the different groups studied, despite the high attitude level toward strategic planning, the awareness level of the participants was not satisfactory. Given that there was a significant correlation between attitude level and awareness level, we can create a more positive attitude in individuals by raising their awareness about the formulation and application of the strategic plan.

Abedini et al's study in 2004[16], titled "Awareness and attitude of the Iranian Medical Science University managers towards development and application of strategic planning", as well as Gilizadeh et al's study in 2011[20], titled "A survey of awareness and attitude of managers of educational and medical centers towards development and application of strategic planning in Tabriz", described the relationship between awareness and attitude as meaningful, which was in agreement with the results of the present study. Therefore, it seems that if individuals have a higher awareness of strategic planning, their attitude will improve as well. Thus, given the importance and essential status of strategic planning in the performance and efficiency of hospitals, plans to increase awareness and, consequently, increase the attitude of senior managers seems indispensable and very necessary.

In Kazemi et al's 2011 study titled "A survey of the level of strategic thinking of the managers of educational departments of Islamic Azad universities in district 10 of Tehran" it was demonstrated that the strategic planning awareness and knowledge of the managers of Islamic Azad universities in district 10 of Tehran was very high[21], while on average, compared to our study, also the attitude of the whole statistical society to the strategic planning was very high. Another study carried out in Belgrade in 2007, showed that teaching strategic planning to hospital managers has a considerable impact on their ability to fulfill the mission, goals and vision of the hospital, [5] and the present study showed a significant difference between the mean awareness and attitude scores of individuals who had passed in-service training in strategic planning and those who had not. 
The results of Gholizadeh et al's study and Abedini et al's study showed that there is a significant and meaningful correlation between education level and awareness and attitude level, which means a higher educational level leads to higher and increased awareness and attitude towards formulation and application of the strategic plan. The present study also showed a significant correlation between education level and awareness and attitude level[16,20]. In this respect, though in the short run it may not be possible to raise the education level of senior managers, in the long run, it is essential to enforce and ensure appropriate planning to raise the education level of senior managers or select and install managers with high education levels to these posts. Another point to note here is that over recent years, due to the expansion and growth of graduate and specialized studies in medical sciences majors, we are witnessing the fact that individuals selected for senior management positions at hospitals are highly educated. However, it should be taken into account that with raised education, comes the imperative to raise knowledge and capabilities of individuals in strategic planning.

\section{Study Limitations}

The study limitation consisted in the small sample size of the participants, as well as uncooperativeness on the side of some senior hospital managers.

\section{CONCLUSION}

The results of this study showed that in all the different groups studied, despite the high level of attitude regarding strategic planning, the level of awareness of the participants was not acceptable. Considering the effectiveness of in-service training in strategic planning on raising managers' awareness and attitude level, individuals' awareness and attitude level, especially hospital presidents who had the lowest awareness level, can be raised through holding in-service training courses. Using managers who are educated in management, due to the fact that they had the highest scores of attitude and awareness in this study, can lead to the effective and operational use of the strategic plan and realization of the goals of the hospital in the specified time frame.

\section{ACKNOWLEDGMENTS}

We are deeply grateful to all the managers of the relevant hospitals who contributed to this research.

\section{REFERENCES}

[1] Tabibi J (2005) Strategic Planning, Second Edition. published cashmere, Tehran: 25 - 89.

[2] Asefzadeh SR, A. (2007) Healthcare planning. First Edition, Hadise Emrooz Publication: 165,183.

[3] Mehri N ( 2008.) Sterategic Plan Of Tabriz University Of Medical Sciences, Department Of Health Services Management, Faculty Of Management And medical Information,. 11-13.

[4] Liu CF, Rubenstein LV, Kirchner JE, et al. (2009) Organizational cost of quality improvement for depression care. Health services research 44: 225-244.

[5] Terzic-Supic Z, Bjegovic-Mikanovic V, Vukovic D, et al. (2015) Training hospital managers for strategic planning and management: a prospective study. BMC Medical Education 15: 25.

[6] García CM, de Val Pardo I (2004) Strategies and performance in hospitals. Health policy 67: 1-13.

[7] Williamson S (1997) Fundamentals of strategic planning for healthcare organizations: Psychology Press.

[8] Hassan Gholipour T, Aghazadeh, H (Summer 2005) strategic plan for small and medium enterprises. Quarterly Journal of Commerce: 100-165.

[9] Mirbalouchzehi Ali, Yazdandoust Mehran, Abdolhakim Ghanbarzehi, et al. (2016) Investigating Knowledge and Attitude of Hospital Manages of Medical Sciences Department of Iranshahr toward Strategic Planning, 2016. International Journal of Medical Research \& Health Sciences 5: 244-246.

[10] Braysvn JM, translated by A. Monavvarian fe (1372) Strategic Planning for Public and Nonprofit Organizations. Public Administration Training Center: 250-251.

[11] Perera FdPR, Peiró M (2012) Strategic planning in healthcare organizations. Revista Española de Cardiología (English Edition) 65: 749-754.

[12] Sadeghifar J, Jafari M, Tofighi S, et al. (2015) Strategic planning, implementation, and evaluation processes in hospital systems: A survey from Iran. Global journal of health science 7: 56.

[13] Thompson JL, Martin F (2010) Strategic management: Awareness \& change: Cengage Learning EMEA.

[14] Abedini Z (1388) knowledge and attitudes of university administrators to develop and apply the 2003 Strategic Plan. Journal of Research and Planning in Higher Education 51: 27-50. 
[15] Asefzadeh S, Rezapour A (1386), health plan, first edition Nshrhdys Today: 163-168-175.

[16] Abedini Z (2004.) Knowledge and attitudes towards the formulation and application Strategic Plan in Iran University of Medical Sciences managers, Iran University of Medical Sciences, School of Management and Medical Information, BSc Thesis. . 23-27

[17] Wells DLTbT, Sj. Maleki, MR. (2005) Strategic Management for Senior Executives, First Edition, Simae Farhang Publication,. 123-126.

[18] Harrison DL (2007) Effect of strategic planning education on attitudes and perceptions of independent community pharmacy owners/managers. Journal of the American Pharmacists Association 47: 599-604.

[19] Kohan A (1388) examining epistemological beliefs and attitudes of managers in strategic planning in higher education universities in the North East of Iran. Journal of Research and Planning in Higher Education 51: 27-50.

[20] Gholizadeh M, Jannati DA, Hadiun F (2011) Evaluation of awareness and attitudes of Tabriz University Hospital administrators in the field of compilation and application of the strategic plan in 2011.

[21] Kazemi M, Nooruzadeh R, Javadipoor M (2011) Evaluation of Strategic Thinking in the Heads of the ejucational Departments at district 10 in Azad University of science. Educational leader and management 4: 133-152.

Citation: Naser Derakhshani, Saber Azami-Aghdash, Mahdiyeh Heydari, Behzad Eshtiag, Ramin Rezapour. "Managers Knowledge and Attitude of Educational Hospitals of Qazvin University of Medical Sciences toward Strategic Planning, 2016." International Journal of Managerial Studies and Research (IJMSR), vol 6, no. 2, 2018, pp. 10-17. doi:http://dx.doi.org/10.20431/2349-0349.0602002.

Copyright: (c) 2018 Authors. This is an open-access article distributed under the terms of the Creative Commons Attribution License, which permits unrestricted use, distribution, and reproduction in any medium, provided the original author and source are credited. 